\title{
Spontaneous Pneumomediastinum Following to a Generalized Tonic - Clonic Seizure
}

\author{
Tonik-klonik Nöbeti Takiben Spontan Pnömomediastinum
}

Cenk Balta

\begin{abstract}
Pneumomediastinum refers to the presence of air in the mediastinum. It is commonly occurs secondary to a perforation of respiratory or gastrointestinal system organs. Primary spontaneous pneumomediastinum is a rare and benign condition that can result from a peripheral pulmonary alveolar rupture. We present here a case of spontaneous pneumomediastinum that occurred following to a generalized tonic-clonic epileptic seizure.
\end{abstract}

Key words: Mediastinum, epilepsy, pneumomediastinum.

\section{Özet}

Pnömomediastinum; mediastende serbest hava bulunmasıdır. Genellikle solunum veya sindirim sistemi organ perforasyonuna bağlıdır. Primer spontan pnömomediastinum periferik pulmoner alveol rüptürünün sebep olduğu nadir izlenen benign bir hastalıktır. Generalize tonik-klonik epileptik nöbet sonrası saptanan spontan pnömediastinum olgusunu sunacağız.

Anahtar Sözcükler: Mediasten, epilepsi, pnömomediastinum.
Pneumomediastinum are classified into two subtypes: spontaneous and secondary. Spontaneous pneumomediastinum (SPM) was described by Louis Hamman who presented a small group of cases in 1939 (1). SPM is a rarely seen, benign and self- limiting disease. Secondary pneumomediastinum is associated with secondary organ injury.

We present here a case report of a patient who developed SPM following a generalized tonicclonic epileptic seizure.
Department of Thoracic Surgery, Şanlıurfa Training and Research Hospital, Şanlıurfa, Turkey
Şanlıurfa Eğitim ve Araştırma Hastanesi, Göğüs Cerrahisi Kliniği, Şanlıurfa

Submitted (Başvuru tarihi): 23.08.2018 Accepted (Kabul tarihi): 21.02.2019

Correspondence (iletişim): Cenk Balta, Department of Thoracic Surgery, Şanlıurfa Training and Research Hospital, Şanlıurfa, Turkey

e-mail: drcenkbalta@gmail.com 


\section{CASE}

A-19-year-old female patient was brought to the Emergency Department with a complaint of cervical emphysema after a generalized tonic-clonic seizure. She had been diagnosed with epilepsy 13 years previously and had been treated with Carbamazepine. Upon physical examination, a cervical subcutaneous emphysema was detected. SPO2: $87 \%$, blood pressure: $110 / 80 \mathrm{~mm}-\mathrm{Hg}$ and heart rate: $70 \mathrm{bpm}$. Free air was detected in the upper mediastinum in a chest $\mathrm{X}$-ray (Figure 1a) and a thorax computed tomography (CT) scan (Figure 1b).

The decision was made to treat the patient conservatively with continuous oxygen inhalation. The patient was discharged after 5 days without complication. There was no recurrence in a 6-month follow-up.

\section{DISCUSSION}

SPM is a rare disease that is characterized by free air in the mediastinum in the absence of a history of thoracic trauma, surgery or any other medical procedure (2). The pathophysiology of SPM was first described in 1944 by Macklin (3) as being a result of a rapid increase in intraalveolar pressure and/or low perivasculary pressure, from were free air may leak to the cervical area, pericardium and peritoneum. This mechanism referred to as the Macklin Effect (3). Such increases in intrapleural pressure have been linked to asthma, infection, interstitial lung disease, cough, emesis and vigorous exercise due to smoking.

SPM is also associated with drug usage (marijuana, cocaine and ecstasy), which can affect the alveolar mem- brane and cause strong pulmonary vasoconstriction, noninvasive mechanical ventilation (4) and dental problems (5). A crunching synchronous sound with a heartbeat (Hamman's sign) can be heard. In the diagnosis of SPM, chest $X$-rays can be useful.

The most common symptoms are dyspnea, dysphagia, pain in the substernal area and subcutaneous emphysema. In the present case, the patient experienced only emphysema in the neck.

The incidence of SPM is between $1 / 7,000$ and $1 / 45,000$ (1), and it is most commonly seen in young male adults (6). Such conservative treatments as resting, continuous oxygen inhalation and analgesia have a good prognosis, and the recurrence rate is low. The true incidence is not clear due to poor recognition and the nonspecific symptoms of SPM.

This uncommon condition has been described in rare case reports, although its classification and treatment guidelines are not certain. Kaneki et al. (6) suggested a detailed classification based on the emphysema level on a chest $X$-ray and $C T$ scan.

Seizure complications mostly take the form of direct injuries, such as head injuries and bone fractures, while pulmonary complications include aspiration pneumonia and neurogenic pulmonary edema. The association between pneumomediastinum and seizures is unusual. Only three case reports have been published about pneumomediastinum and pneumothorax as a complication of a tonicclonic seizure (7-9). A rapid increase in intra-alveolar pressure can be considered suspicious in the etiology.

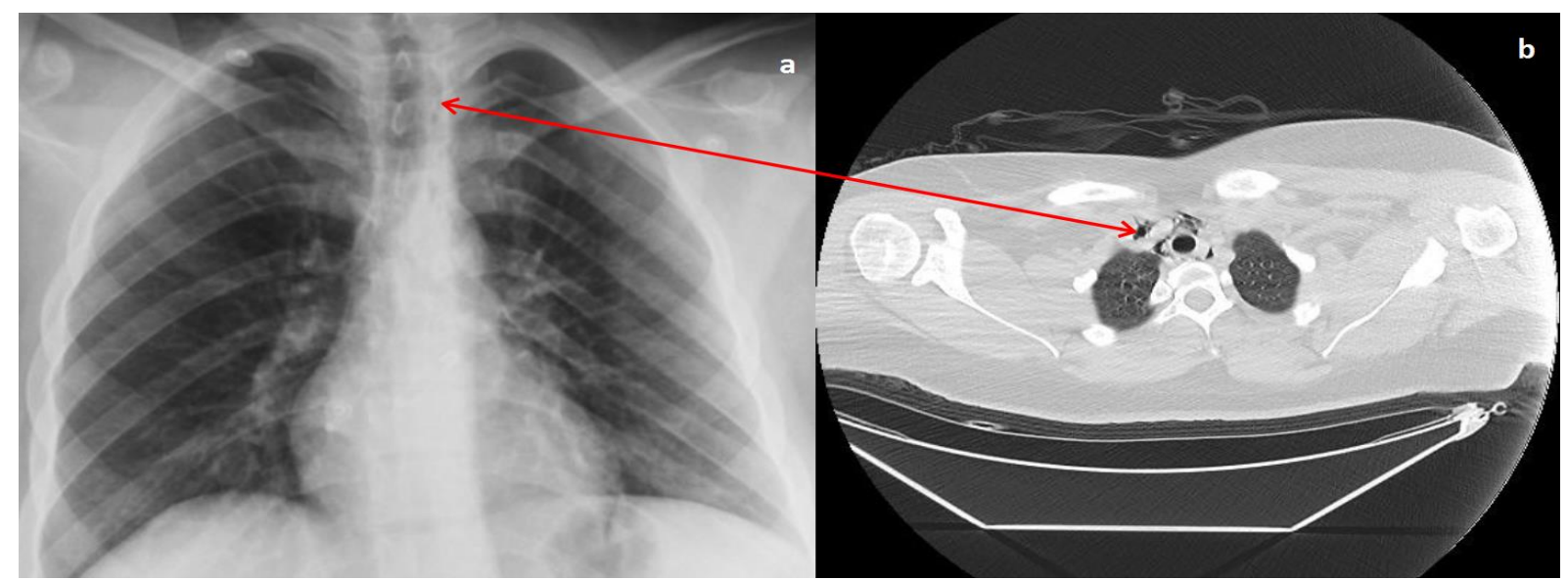

Figure 1: Free air in mediastinum in Chest X-ray (a), Thorax CT scan (b) 
Continuous oxygen inhalation is recommended for the treatment of SPM. Oxygen increases the diffusion pressure of interstitial nitrogen, and promotes the absorption of free air in the mediastinum. We applied continuous oxygen therapy in the present case, and the patient was discharged on the 5 th day of hospitalization.

In conclusion, SPM is a rare and benign condition that is treated with conservative manage-ment. The degree of severity of SPM is not classified clearly, and most cases are not diag-nosed at all. Further studies are needed to determine appropriate treatments and for the classification of the degrees of SPM.

\section{CONFLICTS OF INTEREST}

None declared.

\section{AUTHOR CONTRIBUTIONS}

Concept - C.B.; Planning and Design - C.B.; Supervision - C.B.; Funding - C.B.; Materials - C.B.; Data Collection and/or Processing - C.B.; Analysis and/or Interpretation C.B.; Literature Review - C.B.; Writing - C.B.; Critical Review - C.B.

\section{YAZAR KATKILARI}

Fikir - C.B.; Tasarım ve Dizayn - C.B.; Denetleme - C.B.; Kaynaklar - C.B.; Malzemeler - C.B.; Veri Toplama ve/veya İşleme - C.B.; Analiz ve/veya Yorum - C.B.; Literatür Taraması - C.B.; Yazıyı Yazan - C.B.; Eleştirel İnceleme - C.B.

\section{REFERENCES}

1. Hamman L. Spontaneous mediastinal emphysema. Bull Johns Hopkins Hosp 1939; 64:1-21.
2. Murayama S, Gibo S. Spontaneous pneumomediastinum and Macklin effect: Overview and appearance on computed tomography. World J Radiol 2014; 6:850-4. [CrossRef]

3. Macklin MT, Macklin CC. Malignant interstitial emphysema of the lungs and mediastinum as an important occult complication in many respiratory diseases and other conditions: in-terpretation of the clinical literature in the light of laboratory experiment. Medicine 1944; 23:281 358. [CrossRef]

4. Bakhos CT, Pupovac SS, Ata A, Fantauzzi JP, Fabian T. Spontaneous pneumomediasti-num: an extensive workup is not required. J Am Coll Surg 2014; 219:713-7. [CrossRef]

5. Ruggeri P, Girbino G. Fatal pneumomediastinum associated with use of noninvasive me-chanical ventilation. Respirol Case Rep 2014; 2:126-8. [CrossRef]

6. Kaneki T, Kubo K, Kawashima A, Koizumi T, Sekiguchi M, Sone S. Spontaneous pneu-momediastinum in 33 patients: yield of chest computed tomography for the diagnosis of the mild type. Respiration 2000; 67:408-11. [CrossRef]

7. Curran H, Ross J. Bilateral pneumothoraces and pneumomediastinum complicating a gener-alized tonic-clonic seizure. CJEM 2008; 10:176-8. [CrossRef]

8. Perrotin D, Ged E, Belin T, Kerouredan V. Bilateral pneumothorax complicating a convul-sive crisis. Presse Med 1987; 16:964-5.

9. Çobanoglu U, Melek M, Edirne Y. Pneumomediastinum Cases Due to Non-traumatic Rea-sons. Solunum 2009; $11: 66-74$ 